\title{
委員会報告 DIVISION AND COMMITTEE
}

\section{フラクトグラフィ部門委員会 環境破壊小委員会報告 各種金属破面のさび取り技術についで}

向井喜 彦* 村田雅 人*

1 は じめに

破壊解析に際し, フラクトグラフィは非常に有力な 情報を与允ることは周知の通りであるが，その破壤に 扮いて腐食環境が介入する場合著しい金属溶解やスタ

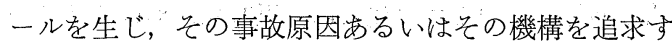
る上で重大な支障をきたす。したがって，腐食環境下 で破壊した破面や破面の保存が悪々さびを生じたもの に対し，その効果的な除錆法とそれによる破面のいた みの具体的な例を収集することは今後の破壊解析に対 し有益な情報を与兄るものと思われる。一方，破面の 除錆法は従来より各者各様汪とんど独自㰸討され， ウハウ的要素孔多く，そ礼らの系統的紹介例はきわめ て少ない。

そこで，本環境破壞小委員会に特いては破面の除錆 に関する討論の機会を設け各委員に資料の提出を願っ た結果，多数の有益な報告がなされたのでこの場を借 りて公開することとした。

\section{2 除錆法の種類と概略}

一般に，従来より行われている破面除錆法を分類す ると次のようになる.

\section{(1) 機械的方法}

a. ブランクレプリカ法; 赤さび $\left(\mathrm{Fe}(\mathrm{OH})_{3}\right)(\mathrm{Fe}$ $\left.\mathrm{CO}_{3}\right)$ なぞ密着性の悪いものには有効であるが黒 さび $\left(\mathrm{Fe}_{3} \mathrm{O}_{4}\right)$ のように密着性の良いものについ ては必ずしも有効でない，他の除錆法(酸洗など) 々組合せて使用されることが多い。

b. 超音波洗浄法; 単独で用いる場合は破面を最 もいためない方法であるが効果が弱く，したがっ て除錆剤中で超音波洗浄しとの除錆効果を加速す るのと用いることが多いただし，この場合，皮 膜破壞にともなら孔食を生じることがあるので注 意を要する。また, 界面活性剤を入れた湯中で長 時間洗浄すると比較的良好な結果を得ることがあ る.

c . 陰極電解法 ; 電解質 (例觉ば, $5 \% \mathrm{H}_{2} \mathrm{SO}_{4}+$ インヒビタ (イビット600), $\mathrm{NaCl}+\mathrm{NaOH}+\mathrm{H}_{2} \mathrm{O}$, ともに $15 \mathrm{~V}, 4 \mathrm{~A}, 1 \sim 3 \mathrm{sec})$ 中で水素を発生させ そのガス圧で除錆する. 他の機械的方法と併用す

\section{ることが多い}

(2) 酸洗法

a. $3 \% \mathrm{HCl}$ アルコール

最も簡便な除錆法であるが浸漬時間が長くなる と孔食を生じる.

b. $3 \% \mathrm{HCl}$ アルコール十インヒビタ(イビット 600 )

鋼, Al の除錆も可能であり実用性の高い除錆 法である.

c. $0.5 \sim 1 \% \mathrm{HCl}$ アセトン

厚いスケールの除去に使用

d. $6 \mathrm{~N}$ 塩酸アルコール $+2 \mathrm{~g} / l$ ヘキサメチレンテト ラミン水溶液

浸清 1 〜 10 分あるいは超音波洗浄 5 〜 30分で除 1)
錆

e. $10 \% \mathrm{H}_{2} \mathrm{SO}_{4}$ +インヒビタ（ネオレスチン）(十超 音波洗浄)

$10 \%$ 硫酸水溶液のみでも良好な除錆効果を発揮 するが，インヒビタ添加によりブランク少なく 破面もほとんどいためない優机た除錆法である。

f. ETA (Ethylene diamine tetra-Acetic Acid Disodium Salt) $0.1 \sim 0.2 \mathrm{wt} \%$ 水溶液

低合金鋼，ステンレス鋼， $\mathrm{Al}$ 合金，Ti などほ とんぞの鋼種で除錆可能で比較的強力な除錆剂 である. したがって, 処理時間10〜30分以上で エッチピットを生じることがあり，特に低合金 鋼では注意を要する.

g. $50 \%$ クエン酸水溶液 $+50 \%$ クエン酸アンモニア 鋼の軽微なスケール除去に用いられブランクは 少ない。

h. $5 \%$ クエン酸アンモニウム（60分超音波洗浄） 上記と同様

（3）アルカリ溶液中での除錆

a. $5 \% \mathrm{NaOH}$ 水溶液 (60分超音波洗浄) 除銷率は低い。

b.アンモニア水溶液けブランクレプリカ

黄銅破面に用い比較的良好な結果を得る場合が あるが黑色皮膜を生じるので注意を要する.

c．アルカリ+青化物の併用 
（4）中性除錆剂

a.シュンマ (主剤, チオグリコール酸, pH 7) チオグリコール酸塩と金属酸化物との溶解度の 高い錯塩を生じ除錆する、鋼，ステンレスなど 広範囲の鋼の除錆が可能で破面をほとんど損耗 しない、また，毒性はほとんどないとの報告が なされている。

（以上，除錆対象を示していないのは，すべて 鋼が詨象である.)

以上，破面の除錆法とえの特徵についてまとめたが， 一般に30分以上の除錆を施しても效果がないときは他 の除錆法を試みた方が良く，超音波洗浄による加速は 破面を傷めることがあるのでその条件を厳密に規定す る必要がある。

\section{3 破面の錆取り例}

除錆法としては前述のごとく多数の方法があるが， 次に各委員が最も実用的であるとしている除錆法につ いて各鋼種別に実例で示す.

(1) 炭素鋼, 低合金鋼

a. $10 \% \mathrm{H}_{2} \mathrm{SO}_{4}$ aq. sol.十ネオレスチン $1 \%$ ，超音 波洗淨 ${ }^{1}$

処理条件 超音波洗浄, $5 \sim 15$ 分, 常温

$$
\text { (70 } 80^{\circ} \mathrm{C} \text { でも可) }
$$

図 1 は, WT80C $\mathrm{H}_{2} \mathrm{~S} 500 \mathrm{ppm}$ 水溶液中に 7 日間浸漬 $\left(\sigma \simeq 0.6 \sigma_{Y}\right)$ 後, 付着した硫化鉄を除 錆し，その腐食隇量を測定した結果であり，速や かな除錆後長期浸漬してもほとんど減量増加は見 られず，優れた除錆法であることがわかる.

図 2 (a)(b)は，炭素鋼の腐食疲労破面( $\mathrm{pH}$ 13，人 工海水 $+\mathrm{NaOH}$ 滴下, $70 \mathrm{cc} / \mathrm{min}, N_{f}=2.14 \times$ $\left.10^{6}, 300 \mathrm{rpm}\right)$ の除錆結果 $\left(10 \% \mathrm{H}_{2} \mathrm{SO}_{4}+1 \%\right.$ ネ オレスチン $25^{\circ} \mathrm{C}$ ，超音波洗浄30分）であるが十分 の除錆効果が認められる.

b. $0.1 \sim 0.2$ wt $\% \mathrm{ETA}$ 水溶液

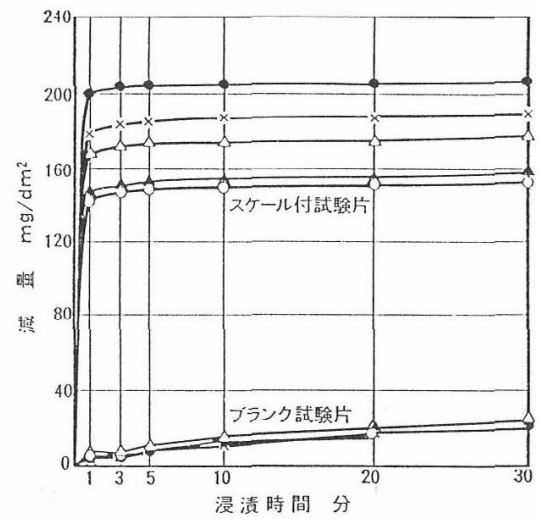

図 $110 \% \mathrm{H}_{2} \mathrm{SO}_{4}+0.5 \%$ ネオレスチン水溶液（80 $\sim 90^{\circ} \mathrm{C}$ ) 中での溶解量（西田）
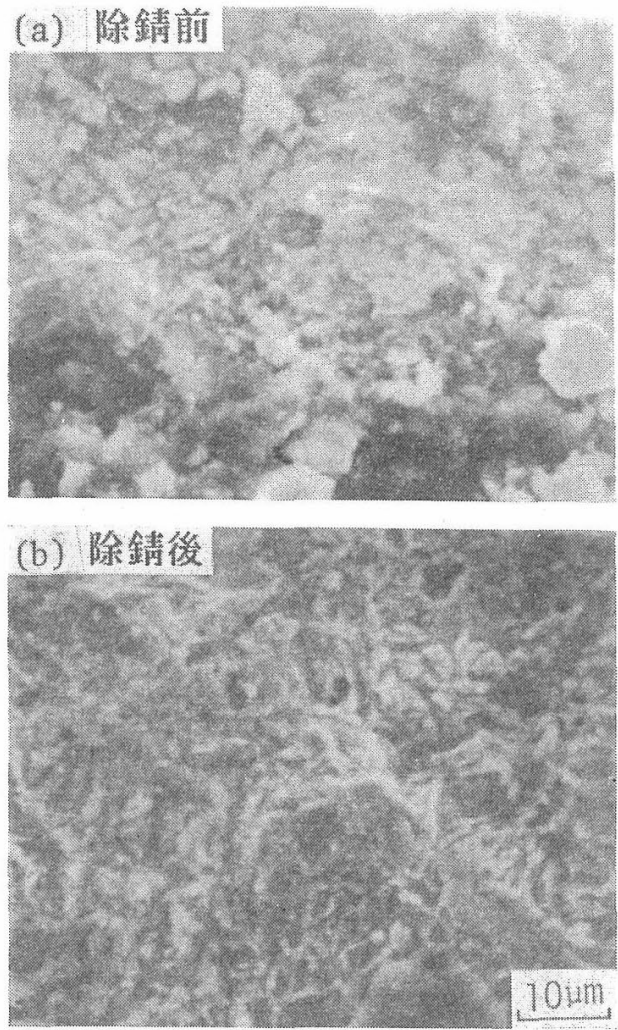

図 2 炭素鋼人工海水中腐食痒学破面の除錆例 (10 $\% \mathrm{H}_{2} \mathrm{SO}_{4}+0.5 \%$ ネオレスチン水溶液)（西田）
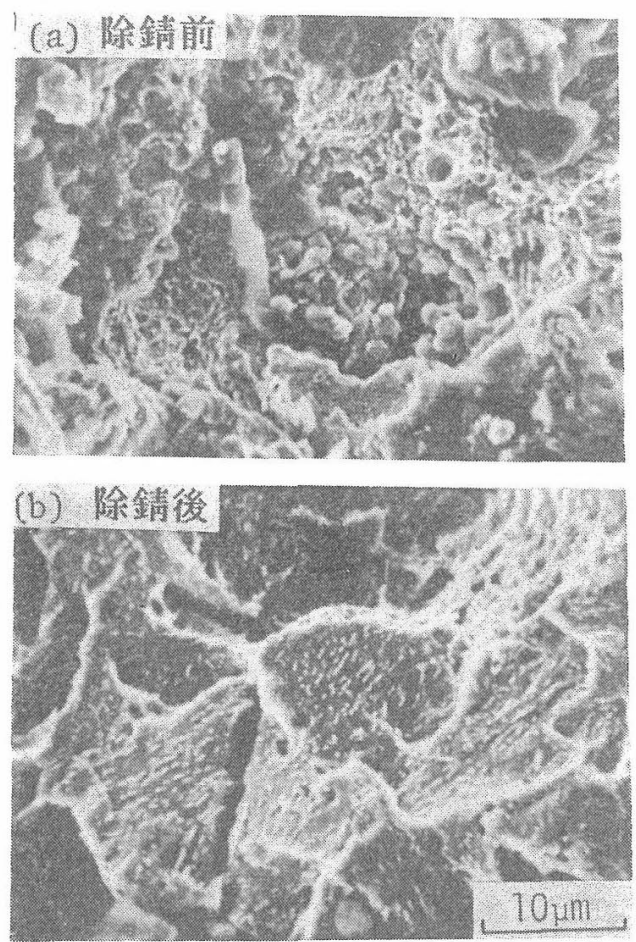

図 3 SCM440 オーバーロード破壤 (0.1 0.2 wt \%ETA) (長尾) 
処理時間が10〜30分以上でピッティング，組織 腐食を生じるので注意が必要である。図 $3(\mathrm{a})(\mathrm{b})$ は SCM 440 のオーバーロード破壞（大気中，海上） の破面の除錆例である。爬い性破面的様相は見ら
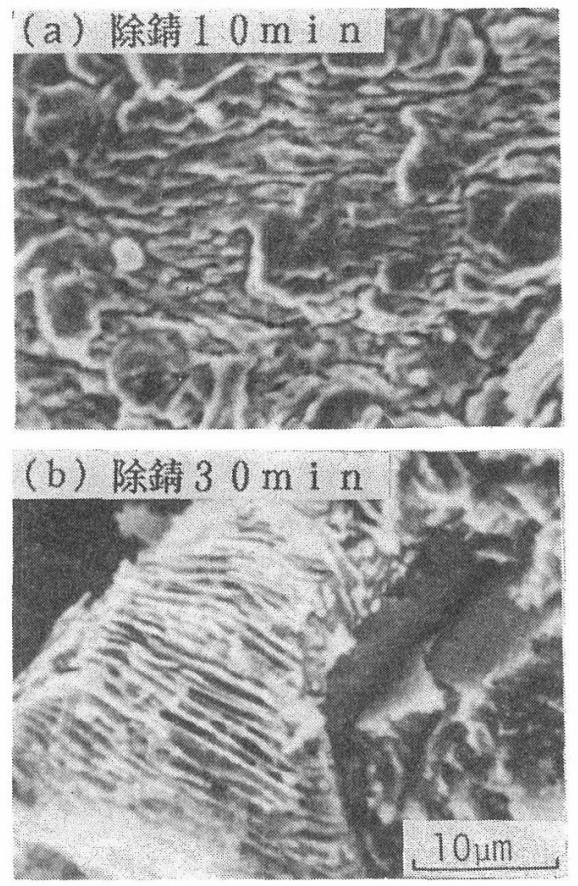

図4 S25Cの $60 \mathrm{ppm} / \mathrm{SO}_{4}{ }^{2-}$ イオンを含む $88^{\circ} \mathrm{C}$ 水溶液中疲労破壤（0.1 0.2 wt $\%$ ETA 水溶液） (長尾)
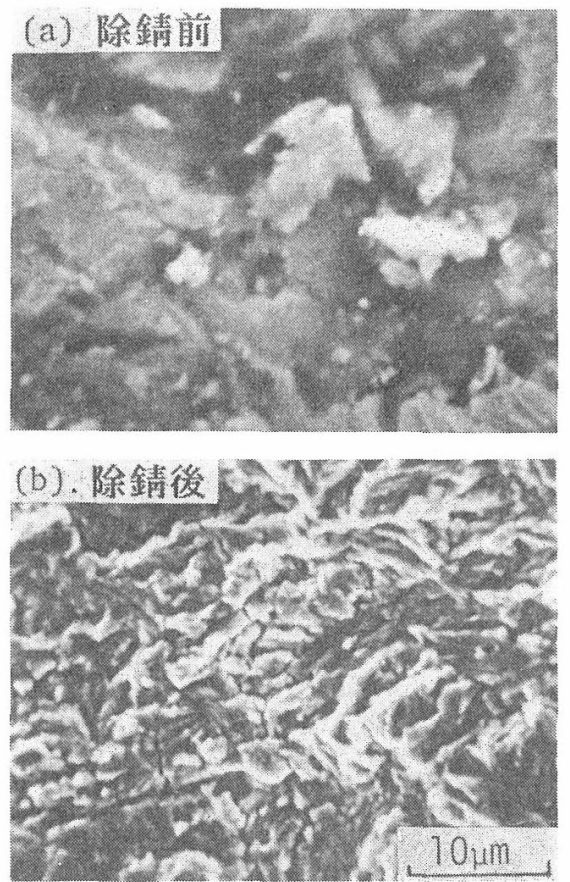

図 5 H53耐熱鋼のC 重油燃焼ガス中痩学破壤 (0.1 0. 2 wt \% ETA 水溶液)（長昆）
れるが破面上かなり腐食されている。（ただし， これはスケーリング時の腐食と思われる.)

また，図 4 (a)(b)はS $25 \mathrm{C}$ の $60 \mathrm{ppm} / \mathrm{SO}_{4}{ }^{2-}$ イ才 ンを含さ $88^{\circ} \mathrm{C}$ 水溶液中に和ける疲労破面の除錆結 果であるが処理時閒10分のときはストライエーシ ヨン様の模様が見られるが処理時間が30分になる と著しい組織腐食を受けパーライト組織があらわ れている.

而熱鋼H5 3(10Cr-Co-Mo-W) のC 重油燃焼ガ ス中に扣ける疲労破面の除錆結果を図 5 (a)(b)に示 す. 除錆効果は著しいがストライエーションは明 りょらでない.

図 6 は，クロム鋼の焼もどしぜい性の最終破断 ぜい性域上思示れるが，ETA 処理時間を30 分以 上としたためにェッチピットを生じた例を示す。

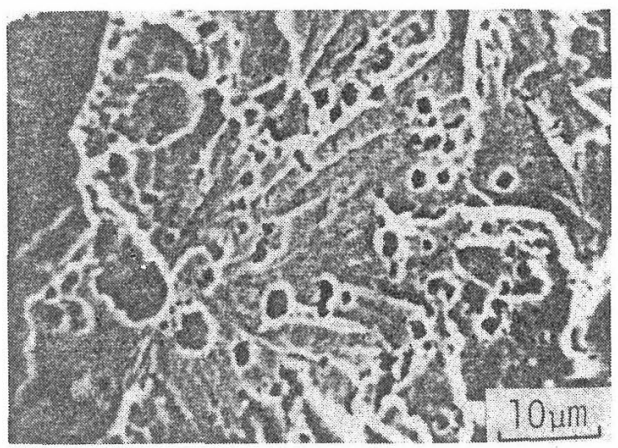

図 6 Cr 鋼ぜい性破面上に生じた除錆材による ピットの例 (ETA，30分以上)

c. $\mathrm{HCl}$ (十インヒビタ)

図 7 (a)(b)(c)は 12Cr-Mo-W-V 鋼の疲学破面で 約 $12 \mu \mathrm{m}$ のスケールが付着していたものを $10 \%$ $\mathrm{HCl}+$ イビット， 約10分の処理を行った結果であ るが，特に高応力域でストライエーション様模様 が明りょらに認められる。このよらに耐食性の優 れた合金では除錆にともなら破面のいたみは少な く，また，その破壊に関する情報が保存されてい ることが多い、ただし，スケールの厚さから考え てストライェーションがその娄の形で保存され ているとは考光にくくむしろストライェーション 生成時のすべり線の腐食の可能性もあり, それら を定量的に評価しき裂進展速度を推定するような 場合には注意を要する。

図 8 は鉄道車轌部品の疲学破面を $0.2 \% \mathrm{HCl}$ 水 溶液 $\left(60^{\circ} \mathrm{C}\right)$ に数秒浸漬した後, ブランクレプリ カで処理したものである。㧤発生点近傍では除 錆してもスケールによる破面の傷久は激しいがき 裂伝ぱ域でストライエーション模様が観察できる. ただし，本来のストライエーションと異なりすべ り線腐食を伴った形で観察されるよらである。 
(a) き裂発生起点 C

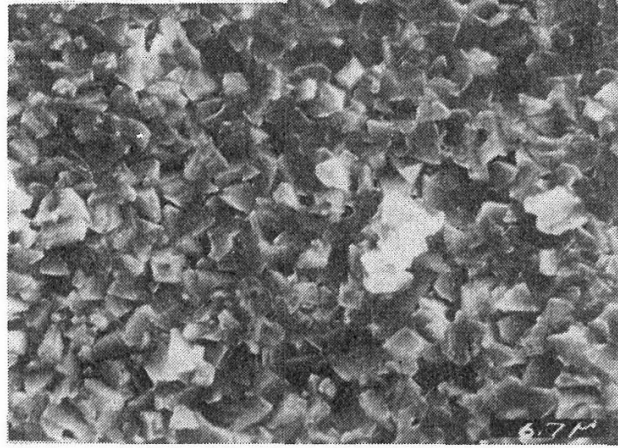

(b) 起点加 5 $1 \mathrm{~mm}$

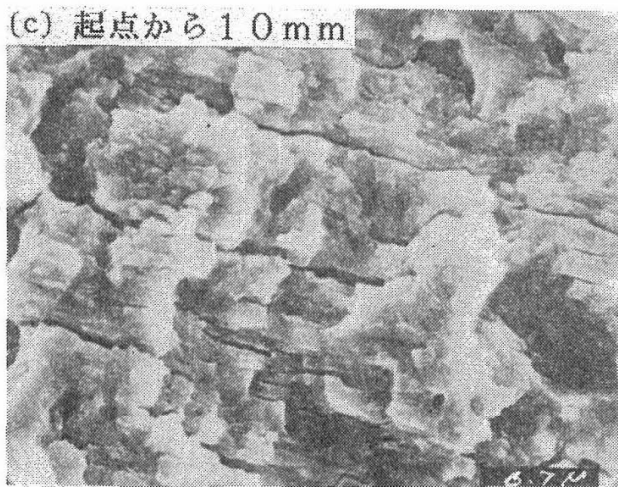

図 $7 \quad 12 \mathrm{Cr}-\mathrm{Mo}-\mathrm{W}-\mathrm{V}$ 鋼疲学破面の除錆( $(10 \%$

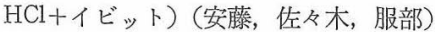

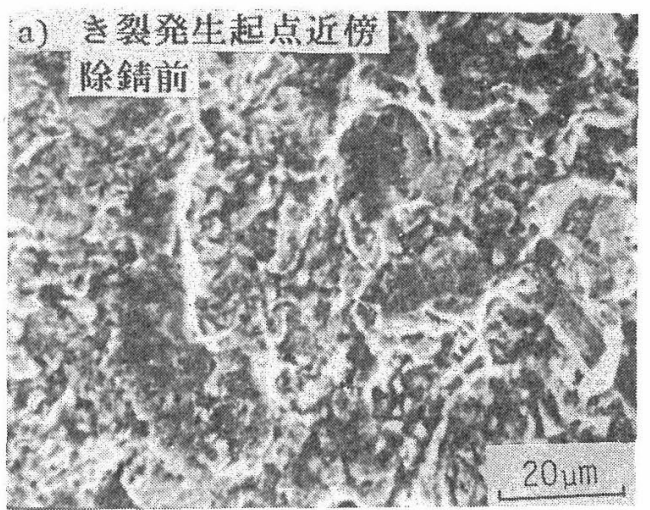

(b) き裂発生起点近傍 6.200302

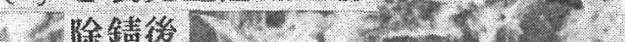

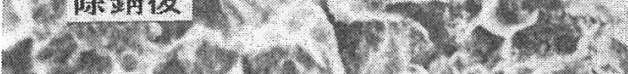

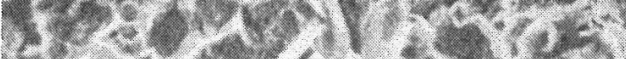

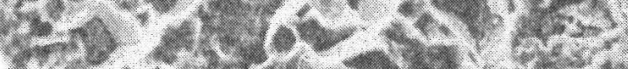

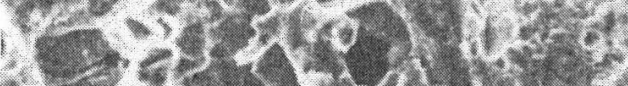

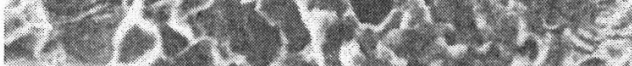

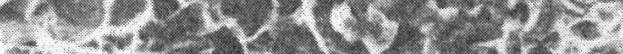

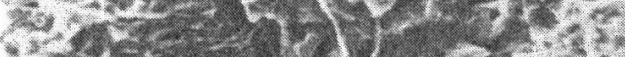

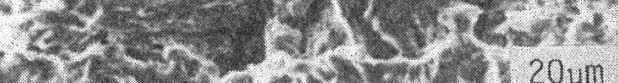

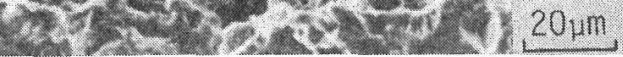

(c) き裂伝播域 除錆前 -

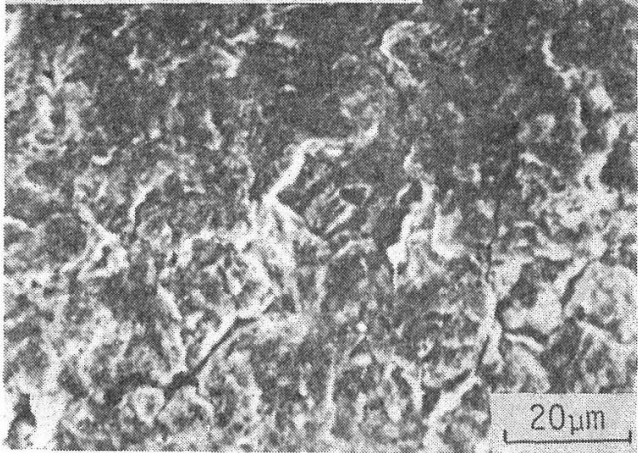

(d) き裂伝播域 除錆後 P -70731 ?
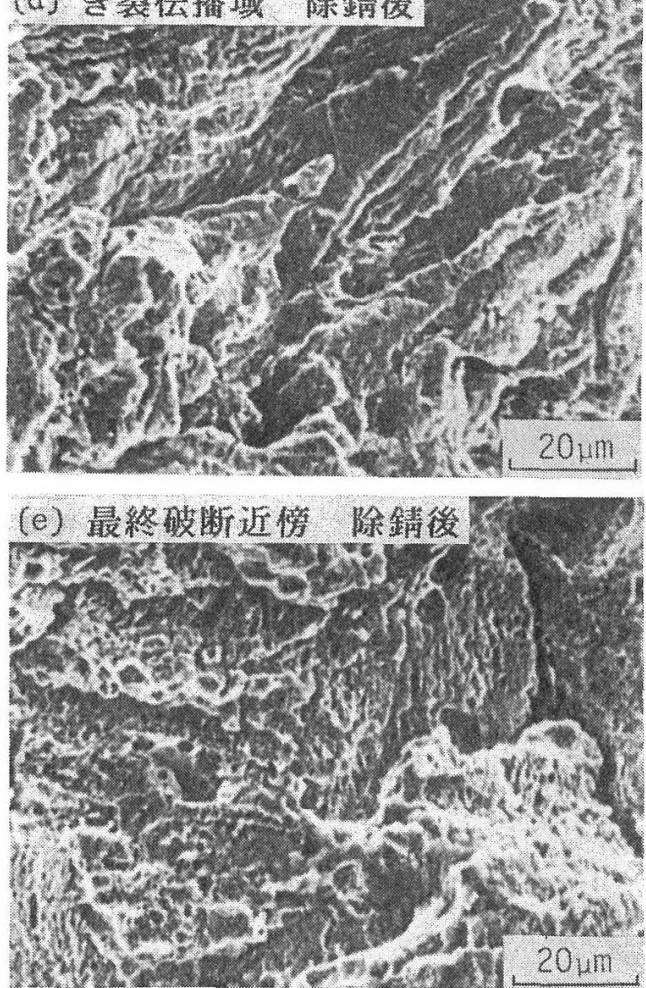

汹 8 鉄道車輛部品の疲労破面 $(0.2 \% \mathrm{HCl}$ 水溶液 $60^{\circ} \mathrm{C}$ ) (小寺沢) 

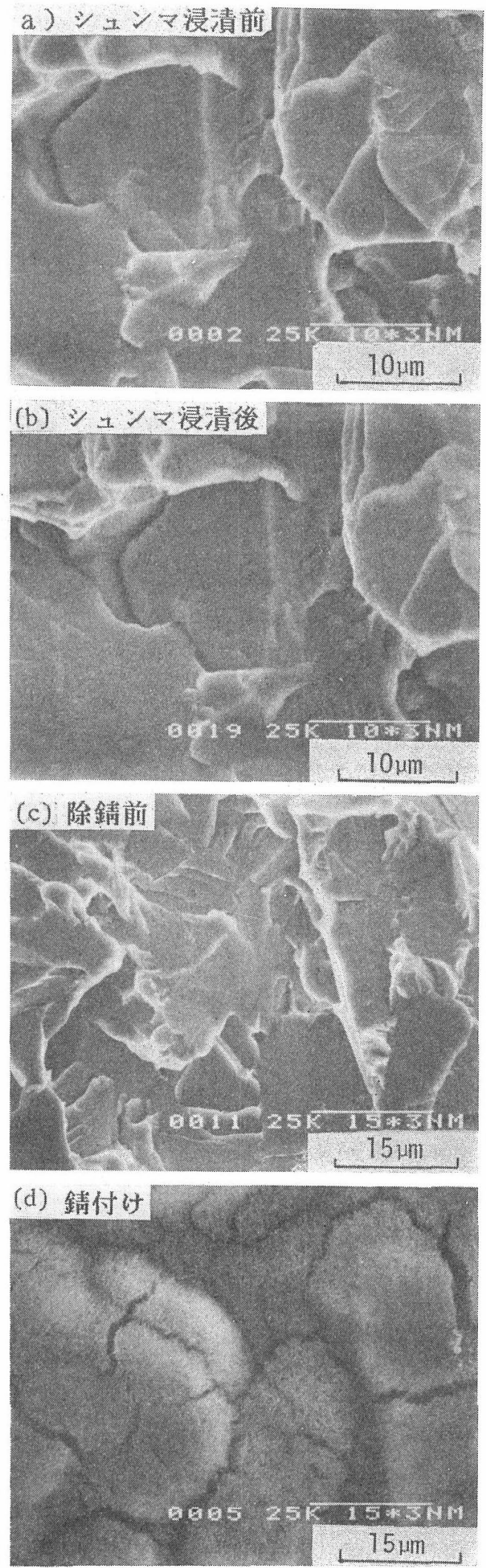

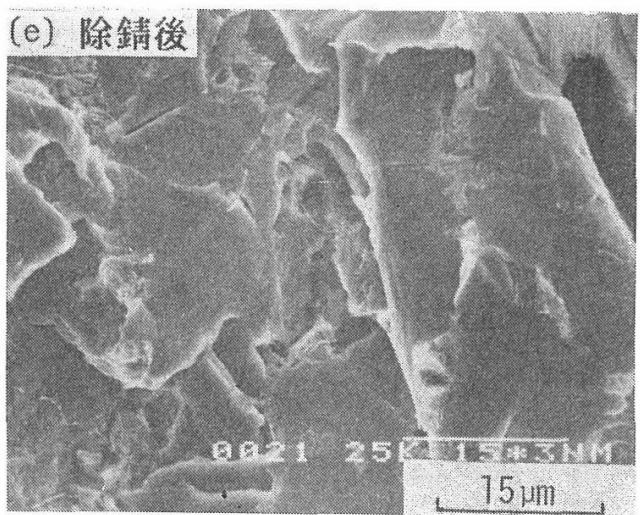

図 9 SM41 低温ぜい性破面の除錆（シュンマ） (村田, 向井)

\section{d. シュンマ}

SM41 材の低温ぜい性破面を蒸留水中（通気） で錆を付着させたものをシュンマ50\%×チルアル コールに30分浸漬し除錆した結果を図 9 に示ず.

ぜい性破面をシュンマに80分浸漬してもティア リッジが少し不明りょうになっている程度でほと えど腐食は見られない。水中に 8 時間浸漬しスヶ 一ル付着後除錆すると組織腐食を生じている。こ れは特とらくシュンマによるものではなく水中腐 食時に生じたものであ万らが，このよらにシュン マは還元性除錆剤であり長期浸漬してもほとんど 破面を傷めない。

(2) オーステナイト系ステンレス鋼

a. ETA $0.1 \sim 0.2 \mathrm{wt} \%$ 水溶液

SUS 304 鋼のC重油排ガス中に拈ける除錆例 を図10に示す．除錆速度は比較的遅く 30 分であス ケールはかなり残存し, 30 分以上続けても破面の 損傷はない、ただし，もとの腐食が激しかったせ いかストライエーションはほとんど見られない。 ETA は耐食合金に対しては破面の損傷をほとん ぞ生じないので，午のよらな金属に刘しては良好 な除錆剂であるといえる。

b . 界面活性剂(湯中 $60^{\circ} \mathrm{C}$ ) 十超音波洗浄60分

SUS 304 鋼のポリチオン酸による事例破面の 除鉓後の写真を図11に示す。受け入れ時は表面全 体に赤さびが出ていたがその密着性が悪かったせ いか非常にきれいに除錆でき明りょらな粒界割れ が見られる。本法は破面を傷めないので他の除錆 法を行う前に一度行って多る価值があるかと思わ れる。

\section{(3) Al 合金}

a. $0.1 \sim 0.2$ wt $\%$ ETA 水溶液

$\mathrm{A} 1$ 合金鋳物の (AC3A-F) 水蒸気中の疲学破壞 を除錆処理した結果を図12に示す。除錆速度は早 

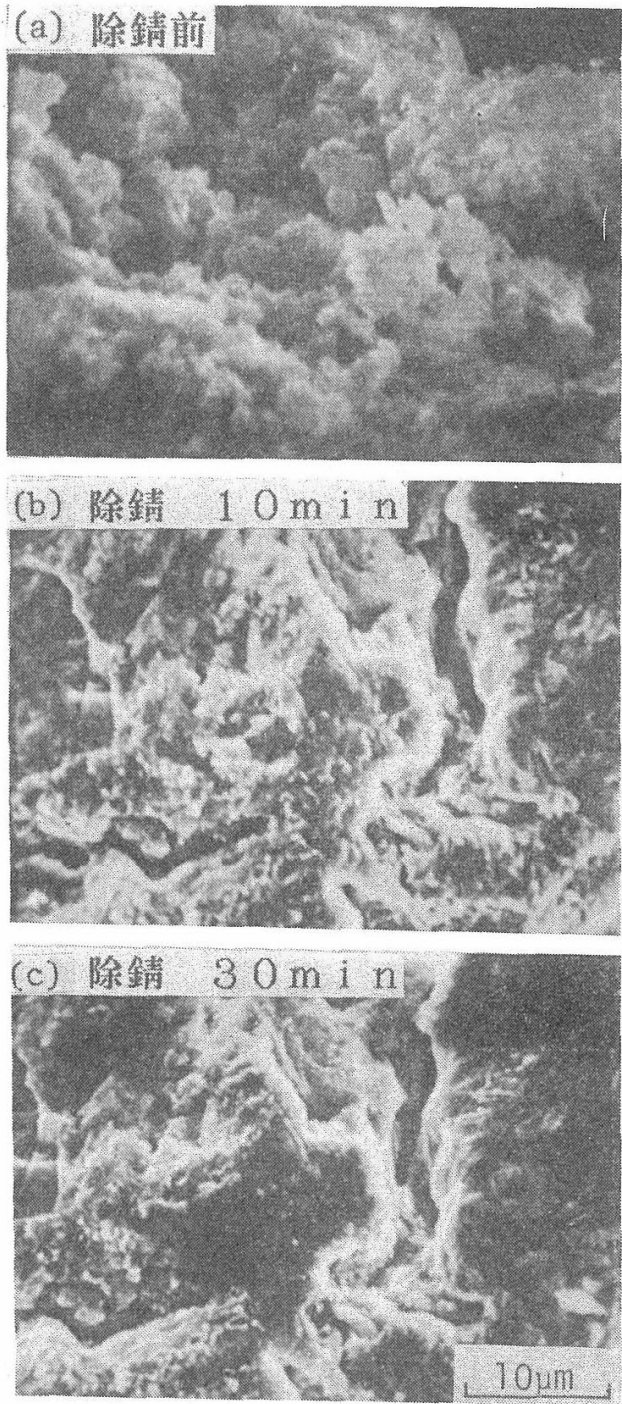

図10 SUS 304 のC重油ガス中の疾学破面 (ETA 水溶液)（長尾）

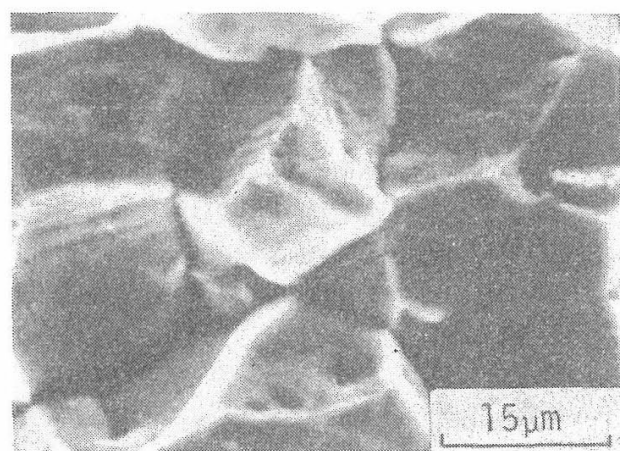

図11 SUS 304 のポリチオン酸による SCC 破面 (界面活性剤十超音波洗浄)（村田，向等)

く10分で医添スケールオフされ破面の損傷は法と んどないまた，ステップに值角方向にわずかで あるがストライェーション様模様が見られる。
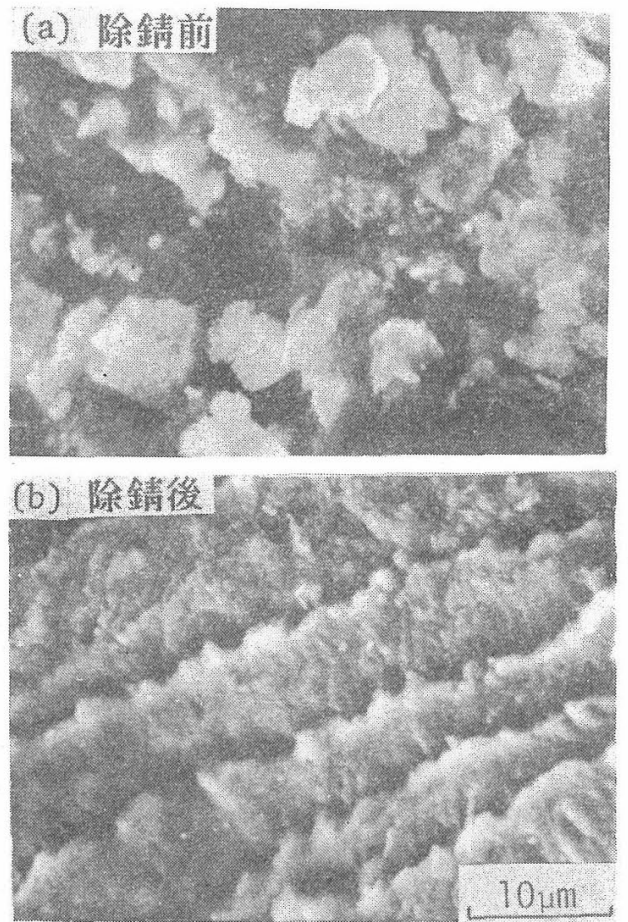

図12 Al 合全鋳物 (AC3A-F) の水蒸気中瘦労 破壞（0.1 0.2 wt\% ETA 水溶液）（長尾）

\section{(4) Al-黄銅}

a. $0.1 \sim 0.2 w \mathrm{t} \% \mathrm{ETA}$ 水溶液

$\mathrm{A} 1$-黄銅のアンモニアによる応力腐食割れ破面
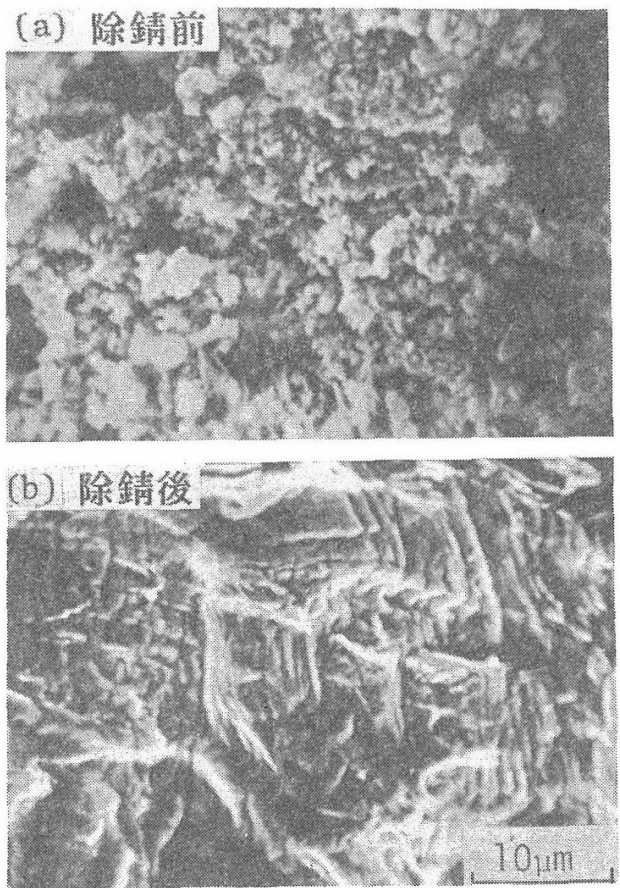

図13 Al-黄銅のアソモニア中 SCC 破面(0.1 $\sim 0.2 \mathrm{wt} \% \mathrm{ETA}$ 水溶液) (長尾) 
の除錆結果を図13に示导. 一般に, 黄銅はアンモ ニア中で tarnish と呼ばれる比較的強固な黒色皮 膜を生じるが，その除錆速度は早く約10分でスケ 一ルオフされ破面の傷みは少ない, 除錆後, 応力 腐食割れ破面に見られるよらなステップ様の流れ 模様的パターンが認められる。

(5) 純 $\mathrm{Ti}$

a. $0.1 \sim 0.2 \mathrm{wt} \% \mathrm{ETA}$ 水溶液

純 $\mathrm{Ti}$ の酢酸水溶液 $\left(144^{\circ} \mathrm{C}\right)+\mathrm{Air}$ 中での応力

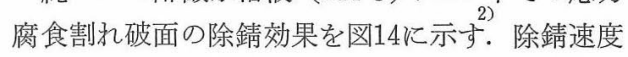
は早く約10分でスケールオフする. 破面は粒界, 粒内混合型のような形態をしていて除錆効果は非 常に良好でむる。
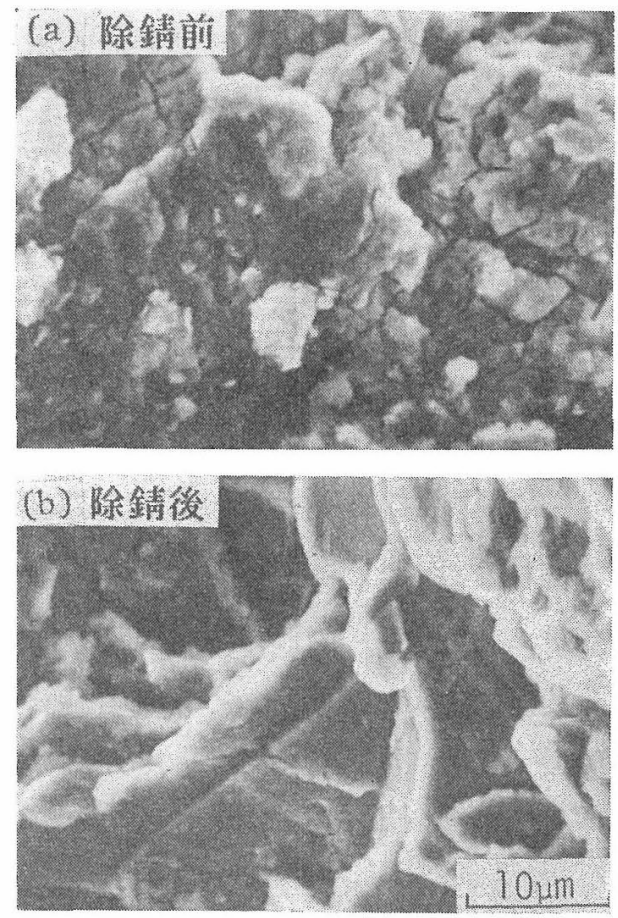

図14 Ti の酶酸水溶液 $\left(144^{\circ} \mathrm{C}\right)+\mathrm{Air}$ 中での SCC 破面（0.1 0.2 wt\%ETA 水溶液）（長尾）

\section{4 各除錆方法の比較とその適用範囲について}

以上，各論的に除錆方法を倹討してきたが，それら の適用範围は次のようにまとめられる。すなわち, 炭 素鋼や低合金銅など，比較的耐食性の低い金属に対す る除錆は酸洗法としてインヒビタを併用することが望 ましい，例光ば，10\% $\mathrm{H}_{2} \mathrm{SO}_{4}+1 \%$ ネオレスチンある いは3〜10\% HCl アルコールーイビットなどが岉げら れる、インヒビタを使用しない場合やETA を使用す る場合は除錆速度は早いが腐食を生じることがあり条 件を注意深く選択する必要がある. また, 中性除錆法 としてはシュンマがあげられる。除錆速度は比較的早 く破面の傷みもほとんどない，適正範团が広いので失
敗率が少なく簡便で有効な除錆法とい光る.さらに， ステンレス鋼， $\mathrm{Ti}, \mathrm{Al}$ 合金など耐食性の高い金属に ついてはより強力な除錆法が要求され， $0.1 〜 0.3 \mathrm{wt}$ $\% \mathrm{ETA}$ 水溶液が挙げられる。この場合マトリックス が耐食性を有するので比較的長い期間浸漬しても破面 のいたみはほとんどなく、委た，Al一黄銅のように tarnish を生じるものについても実用性が高く有効で ある. その他, 有効な除錆法としては Endox $214(\mathrm{~N}$ Y. Alconox 社製) なども優れた除錆剛といわれるが， 主剤との他不明な点が多く，ここでは紹介しなかった。

以上より，除錆後，組織腐食を生じその破面解析が でさない例る紹介したが，これは除錆剤によるいたみ によるものよりも腐食環境下に护㳅破面の溶出とス ケール生成時㐫るいは現場での破面の保存の悪さに伴 らスケールの生成によるところが大きいよらに思われ る.すなわち，破面に対する各除錆方法は現段階に打 いてほとんぞの金属に適用でき条件さ光ある程度選択 すれば十分に害用的であるので事故解析等に対しても 積極的な適用を試みるべさである。

本報告をま之めるに当り多くの資料を心良くご提供 頂きました次の各委員諸氏に深く謝意を表します.

安藤智純 (服部孝博) (三菱重上), 内田仁(姫工大), 江原隆一郎 (三菱重工), 圓城敏男(阪大溶研), 黒田敏 雄(阪大溶研), 大塚昭大 (森要) (名大工), 菊田米男 (阪大工), 荒木孝雄(阪大工), 北川茂(福井大), 小寺 沢良一 (筑波大), 土田栄一郎 (埼玉大工), 長尾幸男 (三井造船), 西田新一(新日鉄), 布村成具(東工大)

(昭和61年 6 月13日 フラクトグラフィシンポジウムにて講演)

\section{参 考 文 献}

1）西田新一, 港口 濼, 金属付着物の除去法, フラクトグ ラフィ環境破填小委員会報告資料, FE14 (1985).

2）長尾幸男, 破面除錆法の检討, フラクトグラフィ環境破 壞小委員会報告資料, FE15 (1985).

3）安藤智純, 佐々木巽, 服部孝博, 破面のさび取り事例紹 介, フラクトグラフィ環境破壞小委員会報告資料, $\mathrm{FE}$ 16 (1985).

4）小寺沢良一, 事故破面の銹取り例, フラクトグラフィ環 境破懐小委員会報告資料, FE17 (1985).

5）村田雅人，向井喜彦，破面の銹による “いたみ” の例， フラクトグラフィ環境破壞小委員会報告資料, FE18 (1985).

6）橘内良雄, 破壞解析の手順と实際, 破壞力学とフラクト

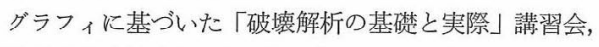
溶接学会東海支部主催 (1985).

7）北川 茂, 黄銅のさび取り,フラクトダラフィ環境破填 小委員会報告資料, FE29 (1986).

8) 佐々木化学(株), シュンマ, 資料. 